\title{
Path towards Business Excellence the Mauritian Experience
}

\author{
Rishi Domun ${ }^{1}$ \\ ${ }^{1}$ Open University of Mauritius, Mauritius \\ Correspondence: Rishi Domun, Open University of Mauritius, Mauritius. E-mail: brdomun@gmail.com
}

Received: September 21, 2016

Accepted: October 13, 2016 Online Published: November 20, 2016

doi:10.5539/ijbm.v11n12p148

URL: http://dx.doi.org/10.5539/ijbm.v11n12p148

\begin{abstract}
Purpose: This paper highlights the preliminary findings of a doctoral research being carried out on the business excellence model used in Mauritius during the past six years. The paper brings out important analysis of unique and original data so much cherished by researchers. It is also a stepping stone for both custodians to improve the organization of business excellence awards and for enterprises to improve areas of business through the adoption of a proper business model.
\end{abstract}

Design/methodology/approach: The paper adopts a mixed method. First, the unique primary data available for six years on participants of the competition is examined quantitatively. Then qualitative content analysis technique is used to probe into the lessons learned from such an essential exercise.

Findings: Some important findings emerged from the analysis of the original data and the lessons learned in the organization of the MBEA competition.

Practical implications: This study will help the four stakeholders, namely, custodians, government institutions, support institutions and enterprises in any country to implement a BE framework with the organization of an Award competition.

Originality/value: The data is original and genuine. It helps to better understand and organize a BE programme in a country. It is the first in Mauritius to address such an issue.

Keywords: business excellence model, business management, business excellence criteria

\section{Introduction}

The world is constantly changing and at the same time, many business paradigms are being questioned. There is an urgent need for businesses to gear up their quality and productivity to survive. This "organization quest for excellence" Talwar (2011) has been there since time immemorial. With the evolution of time, many management theories evolved and were put into practice. Other management theories followed to overcome shortcomings of previous theories. This quest which was taking the form of an "integration of various aspects of quality in excellence models (Mc Donald et al., 2002), started with Deming Prize in Japan in 1951 (Stevens, 1994) followed by the Malcolm Baldrige National Quality Award (MBNQA) (USA) (Talwar, 2011) and the European Foundation for Quality Management (EFQM) Model (Talwar, 2011) in Europe and many other countries.

However, researchers argue that the credibility of these models have to be established to find out whether they are effective approaches to achieve performance excellence. The majority of literature deals only with the format of the models being used and as pointed out by Easton and Jarrel (1998), the data obtained in conjunction with the quality awards are not normally available to researchers. This compromises to a certain extent the possibility of making a proper assessment of Business Excellence (BE) models being used. Mauritius which also embarked on the "quest for excellence" with the organization of the Mauritius Business Excellence Award (MBEA) (MBEA, 2013) also has started questioning the model it used.

This paper highlights part of the findings of a doctoral research being carried out on the business excellence model used in Mauritius during the past six years. It brings out an important analysis of unique and original data so much cherished by researchers. It also provides guidelines for both custodians to improve the organization of business excellence awards and for enterprises to improve areas of business through the adoption of a proper business model.

The case of Mauritius become more interesting with the attributes it has an economy with not much resources at all, presently facing a shortage in labour, as a small island developing state (SIDS), ranked $46^{\text {th }}$ in the Global 
Competitive Index (2015-16) (GCI, 2016) and a welfare state offering free health service and education to all the population, now aspiring to become an upper middle-income country.

\section{Overview of Important Business Excellence Models}

Several academics have provided different definitions and frameworks regarding the BE concept. One of the most revered definitions is that of the European Foundation for Quality Management (EFQM), which defines 'Excellence' (whether it be organisational or business excellence) as the "outstanding practice in managing the organisation and achieving results, all based on a set of eight fundamental concepts" and its framework will "guide your organisation towards achieving success (EFQM, 2012). An overview of the important BE models follows below.

\subsection{The Deming Management Method (DMM)}

The Deming Management Method (DMM) of improving quality was developed by the US Scientist W. Edward Deming, based on the experience he gained in teaching the use of statistical techniques for monitoring and improving industrial processes to top managers, engineers and floor workers in the Japanese manufacturing industry (Stevens, 1994). Subsequently, the Japanese introduced the "Deming Prize", the first globally known business excellence model in 1951 to honor Dr. Deming. Deming focused on market orientation, people involvement, and continuous improvements and advocated the plan, do, check act, (PDCA) cycle for continuous improvements (Talwar, 2010). According to Deming (1986), "improvement of the quality of a product results in a chain reaction that ultimately results in multiple business outcomes: increased market share, sustainability and the growth of a firm and its industryin terms of increase employment."

\subsection{Malcolm Baldrige Model}

The Malcolm Baldrige model is recognised as the best-known excellence model in the world. It is the pillar of most of the models used around the world. The Malcolm Baldrige National Quality Award introduced in the USA in1987, is designed "to help organizational processes, capabilities and results, facilitate the communication and sharing of best practices and serve as a working tool for understanding and managing organizational performance." (NIST, 2015). As the MBEA was based on the Baldrige Model, it is important to examine the evolution of major aspects of the models, the guiding themes, the values and concepts and the criteria during the past ten years. This will help in the assessment of the MBEA.

\section{Baldrige Criteria for Performance Excellence-Diagrammatic representation}

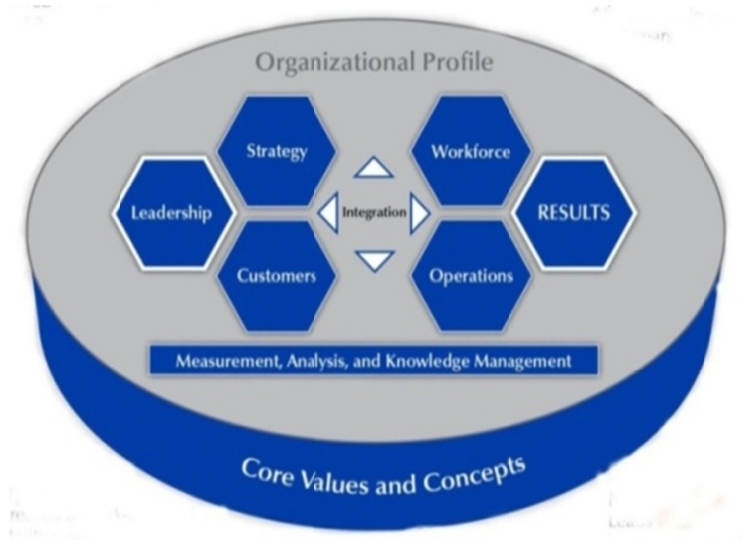

Figure 1. Malcolm Baldrige model-new version (2015)

Source: NIST 2015.

The new version of the Baldrige Criteria for Performance Excellence (NIST, 2015) at Figure 1 is an improvement brought on the diagrammatic representation of the model compared to the previous version. The Core values and concepts dimensions which were only mentioned in the previous versions have now been plugged in the diagram to emphasize its importance. 


\subsubsection{Evolution of Baldrige Core Values 2005-2015}

The guiding philosophy behind a model is important because it embodies a paradigm that cascades down in the model and shows what the model wants to achieve ultimately. The Baldrige framework takes the form of 11 core values which are, visionary leadership, customer-driven excellence, organizational learning personal development, valuing workforce members and partners, agility, focus on the future, management by fact, societal responsibility, managing for innovation, focus on research \& value creation and system perspective. These values are translated into the various criteria of the model. Since 2005 (NIST, 2005, 2006, 2007)) these values have evolved. In 2008 (NIST, 2008), the concept Valuing employees and partners were modified into Valuing workforce members and partners and Social responsibility became a Societal responsibility. The values, however, have undergone a major modification in 2015 (NIST, 2015); the wordings of the values changed. Customer -driven- excellence became Customer-focussed excellence, Organizational and personal learning became Organizational learning and agility. Agility was included in Organizational learning and agility, Focus on the future became Focus on success, and a new concept Ethics and transparency was introduced. The evolution of these values shows that the model has been taking special consideration of workforce, social responsibility, and the environment.

The above evolution in values is confirmed by the various themes adopted since 2005. In 2007 (NIST, 2007), much emphasis is placed on Workforce. Sustainability came in 2009 (NIST, 2009) and Climate in 2015(NIST, 2015). This implies that the model has been going more and more towards the sustainability paradigm, "success now and in the future" (NIST, 2015).

2.2.2 Evolution of Baldrige Criteria 2005-2015

Table 1. Evolution of Baldrige criteria 2005-2015

\begin{tabular}{|c|c|c|c|c|c|c|c|}
\hline 2005 & 2006 & 2007 & 2008 & 2009-2010 & 2011-2012 & 2013-2014 & 2015-2016 \\
\hline \multicolumn{8}{|l|}{ Criteria } \\
\hline Leadership-12\% & $"$ & $"$ & $"$ & $"$ & $"$ & $"$ & $"$ \\
\hline Strategic Planning - 85 & $"$ & $"$ & $"$ & $"$ & $"$ & $"$ & $\begin{array}{l}\text { Strategy } \\
-8.5 \%\end{array}$ \\
\hline $\begin{array}{l}\text { Customer and Market } \\
\text { Focus- } 8.5 \%\end{array}$ & $"$ & $"$ & $"$ & $"$ & $\begin{array}{l}\text { Customer } \\
\text { Focus- } 8.5 \%\end{array}$ & $\begin{array}{l}\text { Customer } \\
\text { Focus- } 8.5 \%\end{array}$ & $\begin{array}{l}\text { Customer } \\
-8.5 \%\end{array}$ \\
\hline $\begin{array}{l}\text { Measurement, } \\
\text { analysis \& knowledge } \\
\text { management- } 9 \%\end{array}$ & $"$ & $"$ & $"$ & $"$ & $"$ & $"$ & $"$ \\
\hline $\begin{array}{l}\text { Human Resource } \\
\text { Focus }-8.5 \%\end{array}$ & $"$ & $\begin{array}{l}\text { Workforce } \\
\text { Focus }-8.5 \%\end{array}$ & $"$ & $"$ & $"$ & " & $\begin{array}{l}\text { Workforce } \\
-8.5 \%\end{array}$ \\
\hline $\begin{array}{l}\text { Process } \\
\text { Management- } 8.5 \%\end{array}$ & $"$ & $"$ & $"$ & $"$ & $\begin{array}{l}\text { Operations } \\
\text { Focus- } 8.5 \%\end{array}$ & $\begin{array}{l}\text { Operations } \\
\text { Focus- } 8.5 \%\end{array}$ & $\begin{array}{l}\text { Operations } \\
-8.5 \%\end{array}$ \\
\hline $\begin{array}{l}\text { Business } \\
\text { Results-45 \% }\end{array}$ & $"$ & $"$ & Results- $45 \%$ & " & $"$ & $"$ & $"$ \\
\hline $\begin{array}{l}\text { Leadership and Social } \\
\text { Responsibility } \\
\text { Results-7\% }\end{array}$ & $"$ & $\begin{array}{l}\text { Leadership } \\
\text { Outcomes-7\% }\end{array}$ & $"$ & $"$ & $\begin{array}{l}\text { Leadership \& } \\
\text { Governance } \\
\text { Outcomes }-12 \%\end{array}$ & $\begin{array}{l}\text { Leadership } \\
\& \\
\text { Governance } \\
\text { Results-12\% }\end{array}$ & $\begin{array}{l}\text { Leadership } \\
\& \\
\text { Governance } \\
\text { Results-8\% }\end{array}$ \\
\hline $\begin{array}{l}\text { Customer Focused } \\
\text { Results-7\% }\end{array}$ & $"$ & $"$ & $"$ & $"$ & $"$ & $\begin{array}{l}\text { Customer } \\
\text { Focused } \\
\text { Results-8.5\% }\end{array}$ & $\begin{array}{l}\text { Customer } \\
\text { Focused } \\
\text { Results-8\% }\end{array}$ \\
\hline $\begin{array}{l}\text { Human Resource } \\
\text { Results-7\% }\end{array}$ & $"$ & $\begin{array}{l}\text { Workforce } \\
\text { Focused } \\
\text { Outcomes-7\% }\end{array}$ & $"$ & $"$ & $\begin{array}{l}\text { Workforce-Focused } \\
\text { Outcomes }-8.5 \%\end{array}$ & $\begin{array}{l}\text { Workforce } \\
\text { Focused } \\
\text { Results- } 8.5 \%\end{array}$ & $\begin{array}{l}\text { Workforce } \\
\text { Focused } \\
\text { Results-8\% }\end{array}$ \\
\hline
\end{tabular}




\begin{tabular}{|c|c|c|c|c|c|c|c|}
\hline $\begin{array}{l}\text { Product \& Service } \\
\text { Outcomes }-10 \%\end{array}$ & $"$ & " & $"$ & $\begin{array}{l}\text { Product } \\
\text { Outcomes } \\
-10 \%\end{array}$ & $\begin{array}{l}\text { Product \& Process } \\
\text { Outcomes }-8 \%\end{array}$ & $\begin{array}{l}\text { Product \& } \\
\text { Process } \\
\text { Results- } 8 \%\end{array}$ & $\begin{array}{l}\text { Product \& } \\
\text { Process } \\
\text { Results-12\% }\end{array}$ \\
\hline $\begin{array}{l}\text { Financial \& Market } \\
\text { Results }-7 \%\end{array}$ & $\begin{array}{l}\text { Financial } \\
\& \text { Market } \\
\text { Outcomes } \\
-7 \%\end{array}$ & $"$ & $"$ & $"$ & " & $\begin{array}{l}\text { Financial \& } \\
\text { Market } \\
\text { Results }-8 \%\end{array}$ & $\begin{array}{l}\text { Financial \& } \\
\text { Market } \\
\text { Results }-9 \%\end{array}$ \\
\hline $\begin{array}{l}\text { Organizational } \\
\text { Effectiveness } \\
\text { Results-7\% }\end{array}$ & " & $\begin{array}{l}\text { Process } \\
\text { Effectiveness } \\
\text { Outcomes-7\% }\end{array}$ & $"$ & " & & & \\
\hline
\end{tabular}

Source: NIST 2005-2015.

$i$. The Baldrige model has presently seven important criteria as shown in Table 1 on Evolution of Baldrige Criteria. These criteria are Leadership, Strategy, Customers, Measurement, analysis, and Knowledge Management, Workforce, Operations and Results (NIST, 2015).

ii. In 2015 the "Criteria category titles were reduced to one word that states the topic" (NIST, 2015). E.g. Strategic Planning became Strategy, Customer and Market Focus became Customers, Human Resource Management became Workforce, Process Management became Operations and Business Results became Results.

iii. Many changes occurred in the items Results criteria and their weights. Leadership and Social Responsibility Results (weight 7\%) changed name in 2007 to become Leadership Outcomes with the same weight. In 2011, it became Leadership \& Governance Outcomes (weight $12 \%$ ), slightly changed to Leadership \& Governance Results (weight 12\%) in 2013 and changed in 2015 to become Leadership \& Governance Resultswith a decreased weight of $8 \%$.

iv. Customer Focused Results which had a weight of $7 \%$ in 2005 saw its weight increased to $8.5 \%$ in 2013 and to come down to $8 \%$ in 2015 .

v. Human Resource Results (weight 7\%) became Workforce-Focused Outcomes (weight7\%) in 2007. In 2011, its weight increases to $8.5 \%$, in 2013 it changedname to Customer Focused Results (weight 8.5\%). In 2015 the weight was decreased to $8 \%$. Logically in the results, the word Focused should have been edited and deleted from the text.

vi. Product \& Service Outcomes (weight 10\%) of 2005 became Product Outcomes (weight 10\%) in 2009. In 2011, it became Product \& Process Outcomes with a decreased weight of 8\%. In 2013, it changed name to Product \& Process Results (weight $8 \%$ ) and in 2015 its weight increased significantly to $12 \%$.

vii. Financial \& Market Results (weight 7\%) in 2005 became Financial \& Market Outcomes (weight 7\%) in 2007. In 2013, it changed name to Financial \& Market Results with the increased weight of $8 \%$ and find its weight increased further to $9 \%$ in 2015 .

viii. The Organizational Effectiveness Results (weight 7\%) of 2005 disappeared in 2007. It is to be noted that Results occupied $45 \%$ of the total weight of the framework.

ix. According to Talwar (2010) "The overall approach of the MBNQA places emphasis on customer satisfaction to achieve competitiveness". In the 2015 version, much emphasis is also being laid on the results for products and processes.

x. The 2015 version of the Baldrige Framework mentions the source of "confusion brought by the word sustainability" (NIST, 2015).

Though the Malcolm Baldrige model is considered as the pillar of most of the models used in the world, the model which is only prescriptive does not indicate what to do to improve. Moreover, it was observed that despite implementing the Malcolm Baldrige model, many enterprises had to face some difficulties or the other. The model has, therefore, to be adapted to the exigencies of businesses and the situations of different nations.

\subsection{The EFQM Excellence Model and the EFQM Excellence Award}

The EFQM Excellence model was introduced in 1991 as a framework to assess applicants for the EFQM Excellence Award (EEA). "It is a non-prescriptive assessment framework that can be used to gain a holistic 
overview of any organisation regardless of size, sector or maturity" (EFQM, 2013). EFQM reviews the EFQM Excellence model every three years to ensure it continues to reflect reality and relevance to the current business environment. The latest "EFQM 2013" was released in October 2012. The main drivers for changing the Excellence model in 2012 reflect the needs for organizations to be more flexible to compete and succeed within the global economic environment. According to EFQM "Excellent Organizations achieve and sustain outstanding levels of performance that meet or exceed the expectations of all their stakeholders" (EFQM, 2013).

The guiding philosophy behind the EFQM framework is, adding value for customers, creating a sustainable future, developing organization capability, harnessing creativity and innovation, leading with vision, inspiration, and integrity, managing with agility, succeeding through the talent of people and sustaining outstanding results. The criteria of the EFQM are almost the same as the Malcolm Baldrige. The EFQM is more detailed about the Enablers and the Results. This aspect makes the model more explicit to businesses.

\subsection{Singapore Business Excellence Model}

Business Excellence was launched in Singapore in 1994. It is aligned with excellence frameworks from the MBNQA, EFQM, Japanese Quality Award and the Australian Business Excellence Award (Jayamaha, Grigg,\& Mann, 2011). It comprises seven categories, namely, Leadership, Planning, Information, People, Processes, Customers and Results. The interesting feature in this model is that it has divided the framework into three elements, namely driver, systems, and results, which makes the model more explicit and user-friendly.

\subsection{Australian Business Excellence Framework (ABEF)}

The Australian Business Excellence Framework (ABEF) (Sai Global, 2010) was developed in 1987 and was inspired by other leading international models such as the EFQM Excellence Model, Baldrige Performance Excellence Criteria, and the Singapore Quality Criteria. The framework has seven main categories, namely Leadership; Customer and Market Focus, People, Strategy\& Planning\& Innovation, Quality and Improvement; Information and Knowledge and Results \& Sustainable Performance. The ABEF is a mature framework which is quite explicit and user-friendly

\section{Methodology}

The paper adopts a mixed method.

First an analysis of the process of the organization of the MBEA is effected.

Second, the unique primary data available for six years on participants of the MBEA competition is examined quantitatively. The data are the results of the assessment of the reports submitted by participating enterprises. As one of the requirements of the MBEA competition, participants who qualified for the next stage of the preliminary stage (mainly screening of data for completeness) have to submit a report according to the format indicated in Table 3 together with the points allotted. These reports were assessed by a panel of three assessors. Two assessors examined the technical aspect, their assessments were averaged to avoid biasness while the financial aspect was assesses by a productivity organization. The assessments were then validated by a Jury Panel comprising representative from various public and private organizations as well as from two universities. The panel has the task of identifying the Awards winners. The Chairman of the Jury Panel is usually a high profile figure in the business world, commanding authority and respect and adding to the credibility of the Award.

Thirdly a qualitative content analysis technique is used to probe into the observations made on the competition to carve out the lessons learned from such an essential exercise

\section{Findings}

\subsection{Process of the MBEA}

\subsubsection{Organization of the MBEA}

The Mauritian competition and the MBEA model were created together with the launching of the MBEA in June 2007 (MBEA, 2013) by the custodian, the Ministry of Industry, Commerce, and Consumer Protection to motivate businesses to continuously improve ways of doing business. The MBEA was inspired from similar awards, namely the Malcolm Baldrige Quality Award implemented in countries adopting leading-edge management practices. Six editions were organized since its launching. The main criteria of the model were: Entrepreneurship / Leadership \& Corporate Governance, Social Responsibility \&Environment-Friendly Initiatives, Strategic Planning and Management, Human Resource Management, Operations Management, Sales Marketing Management and Financial Management. For the purpose of the competition marks (4\%) were given to Organizational Background, Conclusion, and Overall Presentation (see Table 3). 
The implementation process of the MBEA was lengthy, covering a span of twelve months. The process started with four months of submission of application forms, after which there was a pre-selection exercise to identify those that were eligible to participate in the next stage. Those eligible enterprises were given three months to submit their report. Reports submitted by pre-selected enterprises were assessed by a technical team and validated by a Jury Panel based on the defined criteria and visits. A glamorous award ceremony is organized at the end to reward the winners. Usually, the two best enterprises in each of the three categories, namely small, medium and large businesses were rewarded in terms of trophies and certificates. Enterprises that excelled in particular criteria were also rewarded.

As from the fourth edition, assistance was given to enterprises for writing their reports. This contributed to a large extent in raising the standard of participation in the small category. This gives rise to the observation that an enterprise which may not do well in such a competition may be performing well in reality, as the reports they submit may not reflect their real situation. It confirms the observation that there is a difference between participating in a Business Excellence Award and implementing a BE model.

\subsubsection{Participation in the MBEA 2008-2013}

Table 2. Participation in MBEA 2008-2013-category \& sectors

\begin{tabular}{|c|c|c|c|c|}
\hline & Small & Medium & Large & Total \\
\hline Agriculture & 21 & 3 & 5 & 29 \\
\hline Manufacturing & 189 & 57 & 34 & 280 \\
\hline Construction & 14 & 7 & 10 & 31 \\
\hline Wholesale \& Retail & 47 & 10 & 10 & 67 \\
\hline Tourism & 22 & 14 & 9 & 45 \\
\hline ICT & 5 & 5 & 16 & 26 \\
\hline Transport & 2 & 2 & 3 & 7 \\
\hline Financial Services & 13 & 4 & 16 & 33 \\
\hline Services & 43 & 23 & 8 & 74 \\
\hline Education & 5 & 1 & & 6 \\
\hline Health & 10 & 4 & 3 & 17 \\
\hline Others & 29 & 4 & 4 & 37 \\
\hline Total & 400 & 134 & 118 & 652 \\
\hline
\end{tabular}

Source: Ministry of Industry, C\&CP9 (MBEA 2013).

For its six editions, the MBEA received a total of 1,083 applications from enterprises in various categories and sectors. The number of applications was 132 in 2008,197 in 2009,145 in 2010,167 in 2011, 206 in 2012 and 236 in 2013. When viewed as the number of enterprises participating, including repeated participation in several years, the profile of participation in the competition is as shown in Table 2 above.

For all the six editions, 652 enterprises participated by category and by sector. Category-wise, the large enterprises amount to $18 \%$ and the medium and small ones to $21 \%$ and $61 \%$ respectively. Sector-wise, the Manufacturing sector registered $43 \%$ of participation, followed by Wholesale \& Retail trade sector $(10 \%)$ and the other sectors varying between $0.3 \%$ to $6 \%$ participation levels. Medium and Small enterprises account for $88 \%$ of participation in the Manufacturing sector.

\subsubsection{Evolution of Criteria}

Table 3. Evolution of criteria

\begin{tabular}{llllllllll}
\hline & $\mathbf{2 0 0 8}$ & $\mathbf{2 0 0 9}$ & $\mathbf{2 0 1 0}$ & $\mathbf{2 0 1 1}$ & \multicolumn{2}{c}{$\mathbf{2 0 1 2}$} & \multicolumn{2}{c}{$\mathbf{2 0 1 3}$} \\
& & & & & Small & L\& M & Small & L\& M \\
\hline Organizational Background & 5 & 5 & 5 & 5 & 5 & 5 & 5 & 5 \\
Financial management and results & 50 & 50 & 50 & 50 & 70 & 50 & 50 & 45 \\
Leadership & 20 & 20 & 20 & 20 & 12 & 25 & 14 & 25 \\
Social responsibility & 15 & 15 & 10 & 10 & 10 & 10 & $20^{*}$ & $20^{*}$ \\
Strategic planning & 25 & 25 & 25 & 25 & 11 & 25 & 14 & 20 \\
Human resource management & 25 & 25 & 25 & 25 & 12 & 25 & 12 & 25 \\
\hline
\end{tabular}




\begin{tabular}{|c|c|c|c|c|c|c|c|c|}
\hline Operations Managements & 25 & 25 & 33 & 33 & 25 & 30 & 30 & 30 \\
\hline Sales and marketing management & 25 & 25 & 25 & 25 & 40 & 25 & 40 & 25 \\
\hline Conclusion & 5 & 5 & 7 & 7 & 15 & 5 & 15 & 5 \\
\hline Overall presentation & 5 & 5 & - & - & - & - & - & - \\
\hline Total & 200 & 200 & 200 & 200 & 200 & 200 & 200 & 200 \\
\hline
\end{tabular}

* including CSR. Source: Ministry of Industry, C\&CP (MBEA 2013).

During the years, the score allotted to the criteria were amended (Table 3) as per the requirement of the situation. Many members of the jury panel were of the view that SME's should be given a different treatment than large enterprises. That is why, in the case of Small enterprises, the criteria Strategic Planning and Human Resource Management were given less weights. It is to be noted that in the MBEA, marks were given to Background, Conclusion and Overall Presentation as it was a competition. Information and Knowledge Management present in the Baldrige Model was not in the MBEA.

\subsubsection{Comparison of BE Models}

Table 4. Comparison of BE models

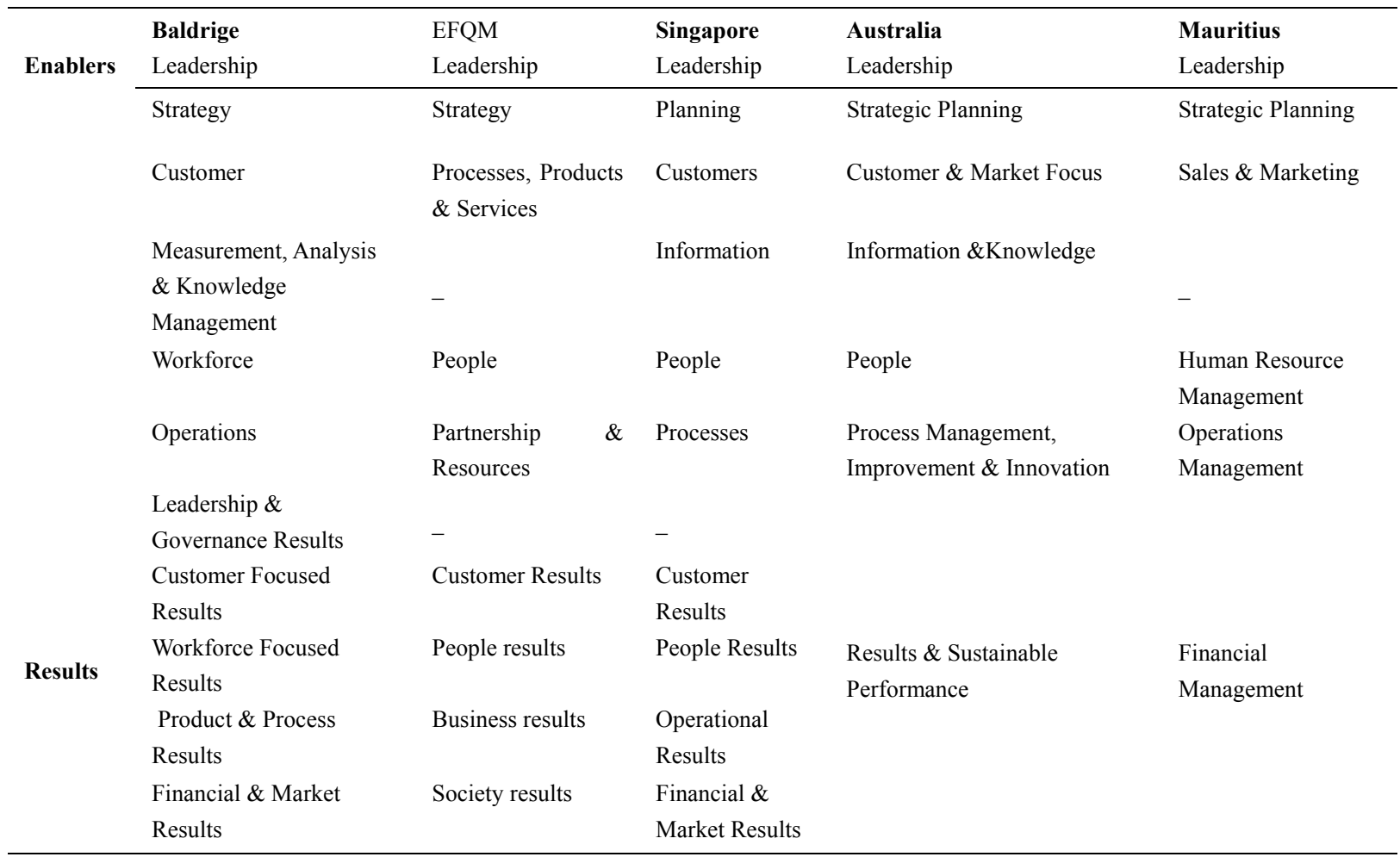

Table 4 compares the essential features of the BE models mentioned above namely, Malcolm Baldrige, EFQM, Singapore, Australia and Mauritius. It was observed that several other models are unique despite having many features of these models (Talwar, 2008).

The frameworks of BE models show critical linkages amongst various criteria and present a roadmap to realizing excellence. Although these frameworks have different shapes and linkages, in most of the models, excellence starts with the criterion "Leadership" and ends with the criterion "Results". The Malcolm Baldrige model framework starts with the criterion "Leadership" and ends with the criterion "Results". The EFQM Model framework also starts with the criterion "Leadership' and ends with the criterion "Results". Several other BE models-for example, the Australian Business Excellence Award and the Singapore Quality Award have their own independent frameworks, however, their focus remains similar to their EFQM and the Malcolm Baldrige models.

\subsection{Quantitative Analysis}

A quantitative analysis is done on the original data available from the participation of enterprises in all the six 
editions of the MBEA. It is based on their assessments.

\subsubsection{Impact on Enterprise}

Table 5. MBEA score of $60 \%$ and above $2008-2013$

\begin{tabular}{lllllll}
\hline $\begin{array}{l}\text { Score of 60\% and above } \\
\text { Category/Year }\end{array}$ & $\mathbf{2 0 0 8}$ & $\mathbf{2 0 0 9}$ & $\mathbf{2 0 1 0}$ & $\mathbf{2 0 1 1}$ & $\mathbf{2 0 1 2}$ & $\mathbf{2 0 1 3}$ \\
\hline Small & 0 & 0 & 2 & 3 & 9 & 5 \\
Medium & 2 & 2 & 5 & 5 & 4 & 6 \\
Large & 3 & 5 & 5 & 8 & 14 & 12 \\
TOTAL & $\mathbf{5}$ & $\mathbf{7}$ & $\mathbf{1 2}$ & $\mathbf{1 6}$ & $\mathbf{2 7}$ & $\mathbf{2 3}$ \\
\hline
\end{tabular}

During the six editions Table 5, it was observed that the number of companies reaching the excellence level of $60 \%$ and above increased from 5 in 2008 to 23 in 2013. It was estimated by the organising body that $60 \%$ and above would be an indication of excellence. Each enterprise was informed of the score that it obtained so that it can take any remedial measure.

\subsubsection{The Overall National Business Excellence Is Below the $60 \%$ Level}

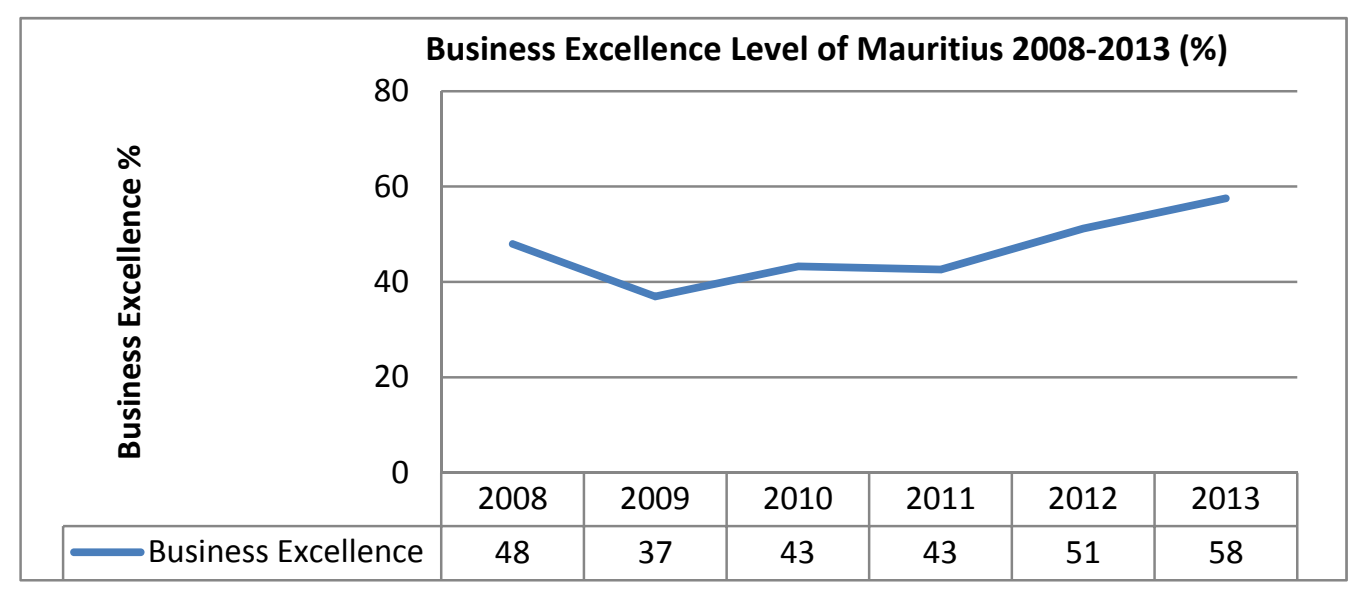

Figure 2. Business excellence level of mauritius 2008-2013 (\%)

The statistical analysis of the data, Figure 2 depicts the relatively low level of Mauritius in terms of the level of business excellence. The $60 \%$ level has not been reached during these 6 years (2008-2013).

The overall business excellence level of Mauritius is below the $60 \%$ level. Very few companies across the globe have crossed the $60 \%$ mark and the aim is to strive towards this $60 \%$ level of excellence to remain competitive.

There is, statistically (based on Mann-Whitney's U Test) no significant difference in the level score between the other years (their p-values being >0.05) except for the scores for the years shown in Table 6 which shows the years with significance differences.

Table 6. Difference of BE level among the years

\begin{tabular}{llll}
\hline Years & & p-value & Comments \\
\hline 2008 & 2009 & .047 & significant difference \\
2009 & 2012 & .000 & significant difference \\
2009 & 2013 & .000 & significant difference \\
2010 & 2013 & .000 & significant difference \\
\hline
\end{tabular}


However, the case for concern here is that during all the six years, the level of BE has been below the $60 \%$ level which is considered as the threshold of excellence. This is bound to ring an alarm bell. The further analysis below shows, specifically, which areas are lagging behind?

4.2.3 Achievement in Main Business Areas Mostly Is Below the $60 \%$ Level

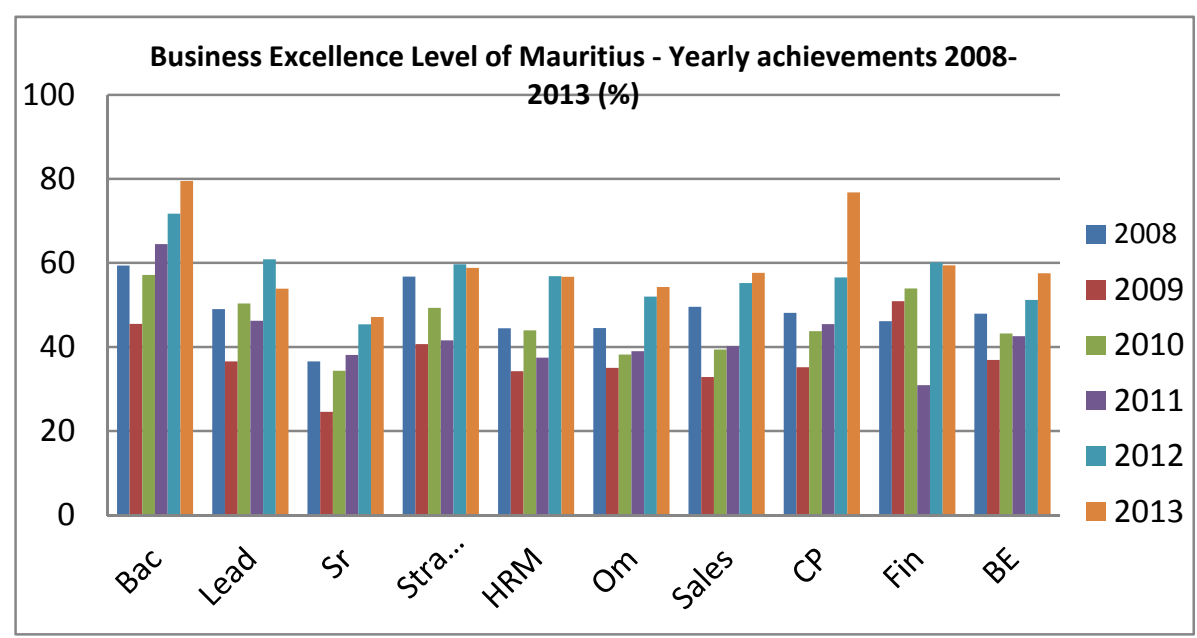

Figure 3. Business excellence level of mauritius-yearly achievements 2008-2013

Figure 3 shows the achievements in the main business areas from 2008 to 2013. The figure clearly shows that most of the nine business areas (except for Background and Conclusion) fall below the $60 \%$ level. The BE level is also depicted.

4.2.4 Significant Differences among the Categories

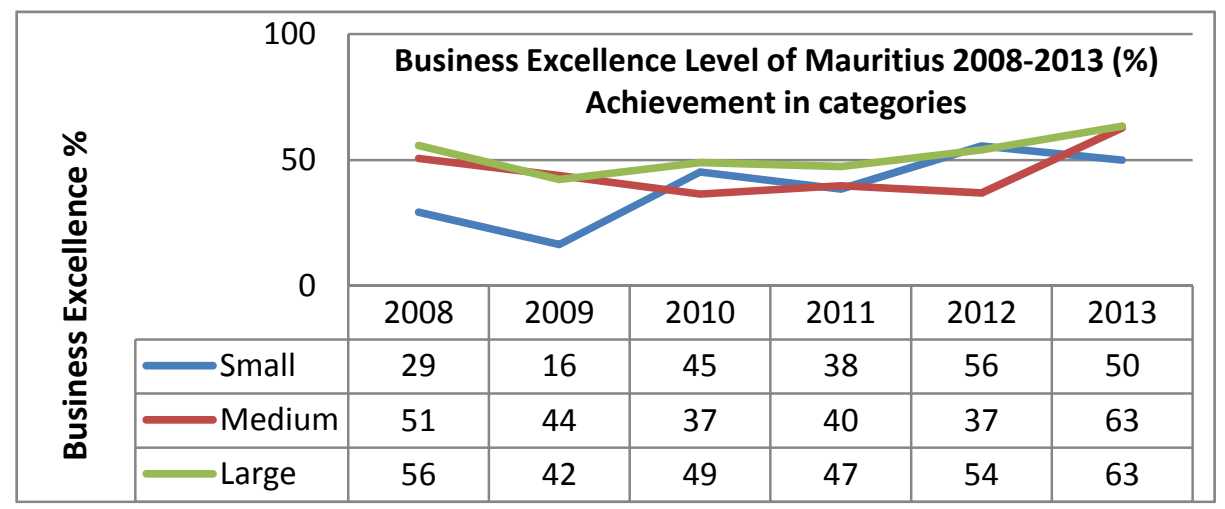

Figure 4. BE level of Mauritius- achievement in categories 2008-2013

The Small and Medium categories (Figure 4) have most of the time been registering low levels of BE. The performance of the Large category has been higher. Most of the time this is related to the quality of the report submitted. 
Table 7. Difference in the categories

\begin{tabular}{|c|c|c|c|}
\hline \multicolumn{4}{|c|}{ Difference in the categories } \\
\hline \multicolumn{2}{|l|}{ Categories } & \multicolumn{2}{|c|}{ p-value } \\
\hline Small & Medium & .658 & no significant difference \\
\hline Small & Large & .004 & significant difference \\
\hline Medium & Large & .018 & significant difference \\
\hline
\end{tabular}

In Table 7 in can be seen that the category Large is significantly different (based on Mann-Whitney's U Test) from the Small and Medium category. The Small category registered a higher level in 2012 because of assistance is given in report writing. Such a difference is important when assistance is being given and in policy making at the authorities' level.

4.2.5 Significant Difference between Performance of Winners and Non Winners

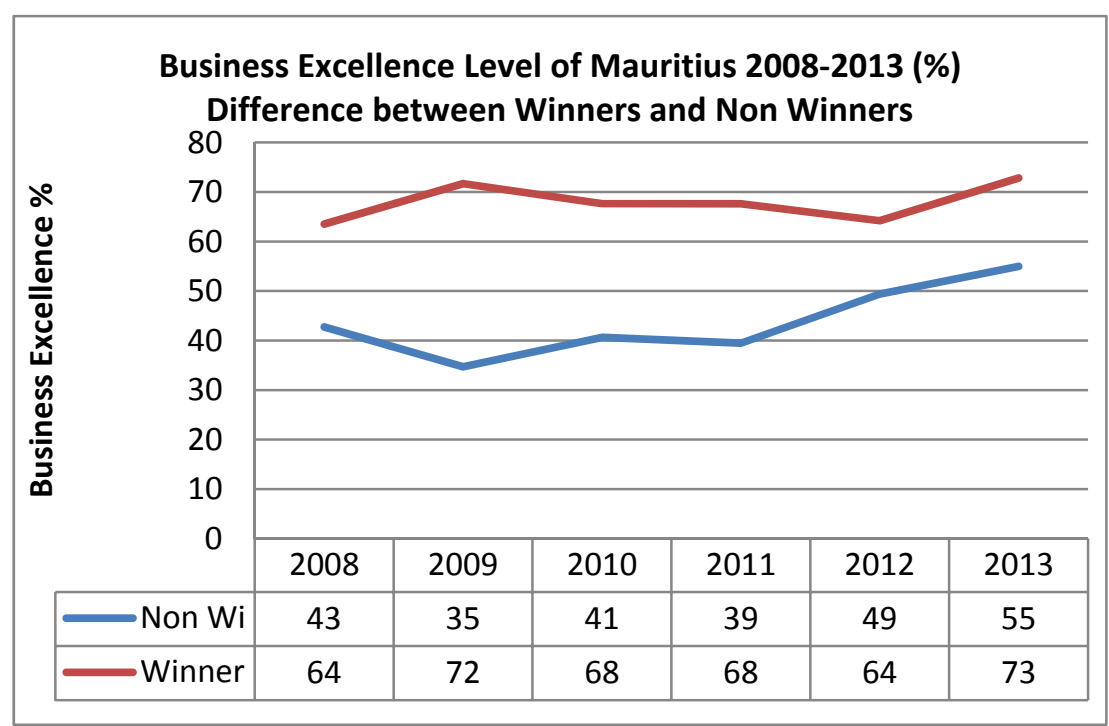

Figure 5. Business excellence level of Mauritius- achievement in categories 2008-2013

Figure 5 shows the difference between the performances of Winners compared to that of Non-winners. The level of the winners is far above those of the Non-winners. Their difference is (p-value: 0.00 at $5 \%$ significance level.) significant as revealed by the Mann-Whitney's U Test. It is to be noted that the mean score of the Winners is over the $60 \%$ line.

The observation that could be made with the two above analysis is that Winners have high BE level, however, when it comes to Category level, the levels are far below the $60 \%$ level. Therefore, much effort will have to be done at category level to raise the level of the Non-winners. The level of the Winners is not too high, though, not more than $72 \%$. Researchers caution against this remaining deficiency in excellence as this may be negative for the enterprise. This is the reason why after sometimes even award winners are seen in difficulties because they already had a percentage of imperfections embedded in them.

\subsubsection{High Correlation between Software Criteria and BE results}

Table 8. Correlations of software criteria to BE (Pearson Correlation)

\begin{tabular}{ll}
\hline Software Criteria & BE \\
\hline Lead & $.910^{* *}$ \\
SR & $.844^{* *}$ \\
Strategy & $.913^{* *}$ \\
HRM & $.901^{* *}$ \\
\hline
\end{tabular}

**. Correlation is significant at the 0.01 level (2-tailed). 
The software criteria mentioned by Peters \& Waterman (1982), namely Leadership, Social Responsibility (SR), Strategic Planning and Human Resource Management are seen (Table 8) to be highly correlated with the BE, implying their importance in a model.

4.2.7 High Correlation between Enabler criteria, Process, and Results

Table 9. High correlation between enabler criteria, process and results

\begin{tabular}{|c|c|c|c|c|c|c|c|c|}
\hline & \multicolumn{4}{|c|}{ Enablers } & \multicolumn{2}{|l|}{ Process } & \multicolumn{2}{|c|}{ Results } \\
\hline & Lead & $\mathrm{Sr}$ & Strategy & HRM & Om & Sales & Fin & $\mathbf{B E}$ \\
\hline Lead & 1 & $.737^{* *}$ & $.829^{* *}$ & $.838^{* *}$ & $.825^{* *}$ & $.806^{* *}$ & $.293^{* *}$ & $.862^{* *}$ \\
\hline $\mathrm{Sr}$ & $.737^{* *}$ & 1 & $.738^{* *}$ & $.738^{* *}$ & $.768^{* *}$ & $.759^{* *}$ & $.286^{* *}$ & $.805^{* *}$ \\
\hline Strategy & $.829^{* *}$ & $.738^{* *}$ & 1 & $.838^{* *}$ & $.839^{* *}$ & $.818^{* *}$ & $.297^{* *}$ & $.884^{* *}$ \\
\hline HRM & $.838^{* *}$ & $.738^{* *}$ & $.838^{* *}$ & 1 & $.837^{* *}$ & $.802^{* *}$ & $.344^{* *}$ & $.865^{* *}$ \\
\hline Om & $.825^{* *}$ & $.768^{* *}$ & $.839^{* *}$ & $.837^{* *}$ & 1 & $.863^{* *}$ & $.340^{* *}$ & $.895^{* *}$ \\
\hline Sales & $.806^{* *}$ & $.759^{* *}$ & $.818^{* *}$ & $.802^{* *}$ & $.863^{* *}$ & 1 & $.339^{* *}$ & $.894^{* *}$ \\
\hline Fin & $.293^{* *}$ & $.286^{* *}$ & $.297^{* *}$ & $.344^{* *}$ & $.340^{* *}$ & $.339^{* *}$ & 1 & $.413^{* *}$ \\
\hline BE & $.862^{* *}$ & $.805^{* *}$ & $.884^{* *}$ & $.865^{* *}$ & $.895^{* *}$ & $.894^{* *}$ & $.413^{* *}$ & 1 \\
\hline
\end{tabular}

Table 9 shows the following:

- High Correlation between Enablers and Process

- High Correlation between Enablers and BE

- $\quad$ High Correlation between Process and BE

- Low Correlation between Enablers and Financial management

- Low Correlation between Process and Financial management

This shows the importance of including Enablers, Process and Result aspects in a BE model.

\subsubsection{Importance of Findings of Quantitative Analysis}

The findings of the quantitative analysis lead to the following recommendations:

a) Given that the overall level of business excellence is quite low, the effectiveness of the model and weights has to be questioned.

b) The weight used for the model is also questioned and compared with other models.

c) High weighing has to be given to the software criteria of Peters \& Waterman (1982).

d) Enterprises have not mastered the software criteria (Peters \& Waterman, 1982.

e) The competition was dominated by the participation of SME's (82\%) as opposed to large enterprises $(18 \%)$.

f) The small and micro enterprises require different types of intervention.

g) The criteria Knowledge and Information present in Baldrige Criteria and EFQM is absent in the MBEA, it will have to be added.

\subsection{Qualitative Content Analysis}

A content analysis has been effected on anSWOT-analysis carried out by the Custodian on the organization of the MBEA

\subsubsection{Assessment of the Organization of the MBEA}

In May 2014, an assessment of the organisation of the MBEA was made to gauge whether the objectives set have been reached and identify the strengths, weaknesses, opportunities and emerging threats (SWOT) for the MBEA competition. A feedback was obtained from all the 652 participants of the MBEA. The assessment presented both the positive points and weaknesses of the MBEA. Following the assessment report, the custodian decided not to go ahead with other editions of the Award. The salient feature of the report described below give the strengths, weaknesses, opportunities and threats facing the organization of the MBEA. 


\subsubsection{Strengths}

The strength of the MBEA was highlighted during the Minister's speech in 2012. "This competition is allowing the participants to gain new insights in critical areas of total quality management and it will help meet the challenge to raise efficiency and effectiveness as the key elements of productivity" (MOICCP, 2012).

Some of the strengths of the competition identified in the report were: all companies were sensitized on best business practices; many winners enjoyed playing role models for others to emulate; the number of enterprises scoring $60 \%$ and above increased ; many enterprises were able to rectify their weaknesses from written feedbacks they got from the organizer; the good image of the MBEA had encouraged other stakeholders to organize similar Award Competitions and its has spurred a greater awareness for quality and productivity.

\subsubsection{Weaknesses}

The weaknesses of the competition identified were a low level of participation from the Large category (19\%), from large enterprises in Manufacturing sector (6\%), Wholesale and Retail trade (17\%) and other sectors between $3 \%$ to $6 \%$. A low level of improvement was also noted: it was estimated that only $24 \%$ viz. 144 out of the 652 participating enterprises registered an improvement in their business following their participation in the $M B E A$; improvement recorded in business practices for large manufacturing enterprises represents only $3 \%$ of a total of the 652 participants; itwasestimated that only $5.8 \%$ (40) of the total number of participating enterprises (652) have registered an increase in their labour productivity out of which the manufacturing sector represents $2.9 \%$.

Some other weaknesses noted were: the number of enterprises which do not fully benefit from the MBEA either by not submitting information or reports for assessment, amount to $78 \%$ of total participation; the small category accounts for most of the dropouts, i.e., $82 \%$. Saturation-after repeated participation, many enterprises do not participate again as they already know their weaknesses through the feedback given to them. Some winners, are seen to be in difficulty after some years

\subsubsection{Opportunities}

As opportunities, the MBEA was found to provide a framework similar to the Malcolm Baldrige Model for companies to improve their best business practices. It created awareness for enterprises to adopt best business practices and address their weaknesses as illustrated by the words of the Minister at that time:

"Let me remind you that the first edition of the MBEA organized in 2008 has been a resounding success from the point of view of organization and sensitization of enterprises to the best business practices." (MOISCR, 2009),

\subsubsection{Threats}

The fact that SMEs and its supporting institutions did not fall under the purview of the custodian of the MBEA, it made it difficult to canvass and assist SMEs to adopt best business practices via the MBEA Competition.

For the last two editions, Crafts was added as a sector in the Small category for the MBEA. This attracted many micro enterprises which had not yet adopted all the areas of a business. Most of them do not have audited accounts and their level in business practice is very low, they were not able to benefit from the competition.

Moreover, enterprises which have participated once in the MBEA become aware of their weaknesses and do not participate again; they have reached a level of saturation in terms of interest.

Contrary to other competitions for businesses organized concurrently, No cash prize was given for the MBEA and this was causing a loss of interest.

\subsubsection{Importance of the Findings of the Content Analysis}

The findings of the qualitative analysis lead to the following conclusions:

a) When there is transparency in the organisation of such a competition it creates a good image for the competition in the long run.

b) Participants are able to gain new insights in business management and are able to rectify their weaknesses.

c) MBEA was marked by low participation of Larger enterprises.

d) The $22 \%$ of participating enterprises which recorded an improvement in their business is considered a relatively low achievement of the MBEA.

e) At certain stage, there was a level of saturation in participation for many enterprises.

f) The Custodian should be close to the sectors it is covering in the competition. 
g) Some winners are seen to be in difficulties after some time.

h) Many efforts have to be done to encourage participation in the Awards competition.

i) SME' need special support.

j) There is a direct relationship between the quality of reports prepared and the score obtained by the participating enterprise.

\section{Recommendations}

Table 10. Framework for organization of BE award

\begin{tabular}{|c|c|}
\hline \multicolumn{2}{|c|}{ What the 4 stakeholders have to do in the organization of a BE Award } \\
\hline Stakeholders & Actions to be taken \\
\hline \multirow[t]{17}{*}{ Custodians } & organize one award only \\
\hline & efforts to improve $\mathrm{BE}$ \\
\hline & increase eagerness to participate \\
\hline & aggressive advertising \\
\hline & make participation easier \\
\hline & encourage participation \\
\hline & question effectiveness of the model \\
\hline & revise model \\
\hline & add criteria \\
\hline & ensure exactness of reports \\
\hline & assistance for report writing for small enterprises \\
\hline & determine proper weight of the model \\
\hline & ensure expertise of assessors \\
\hline & upgrade of BE in all 3 categories \\
\hline & address the difference in categories \\
\hline & address the difference between winners and non-winners \\
\hline & custodians should have an upper hand of all sectors \\
\hline \multirow[t]{4}{*}{ Government } & formulate policies for leverage of BE in different categories \\
\hline & educate businesses \\
\hline & encourage participation \\
\hline & specific policies for small \\
\hline \multirow[t]{5}{*}{ Support Institutions } & increase understanding of Software criteria \\
\hline & increase understanding of Enablers Results \\
\hline & increase understanding of Financial management \\
\hline & educate businesses \\
\hline & encourage participation \\
\hline \multirow[t]{2}{*}{ Enterprises } & companies to know and write on elements of BE well \\
\hline & apply the elements of BE as a model to reach $60 \%$ level \\
\hline
\end{tabular}

The recommendations that emerge from the above analysis is presented in the form of a framework for the organisation of a BE Award. It indicates what the four stakeholders which are the Custodian, Government, Support Institutions and Enterprises involved in the organization of BE Award should do to ensure the successful organisation of such Award.

\section{Conclusion}

The paper has first highlighted the level of business excellence in the Mauritius business landscape. It has also generated a framework that can be used by the four stakeholders involved in BE in any country. It will help countries to leap frog in the organisation and implementation of BE and avoid committing errors. This serves the purpose enumerated by researchers, namely Easton and Jarrel (1998) that BE models should help custodians to study other models, examine their context and gauge the effectiveness of other models.

\section{References}

Deming, W. E. (1986). Out of the crisis. Cambridge, Mass: Massachusetts Institute of Technology, Centre for 
Advanced Engineering Study.

Easton, G. S., \& Jarrell, S. C. (1998). The effects of total quality management on corporate performance: An empirical investigation. Journal of Business, 71, 253-307.

European Foundation from Quality Management. (EFQM) (2012). EFQM Excellence Model 2013 (Kindle Location 1328). Retrieved from http://www.efqm.org

Grigg, N., \& Mann, R. (2008). Review of the Australian Business Excellence Framework: A comparison of national strategies for designing, administering and promoting Business Excellence Frameworks. Total Quality Management \& Business Excellence, 19(11), 1173-1188.

Jayamaha, N., Grigg, N., \& Mann, R. (2011). Empirical analysis of the Baldrige Criteria as both an organisational performance. Measuring Business Excellence, 15(1), 20-33.

Mauritius Business Excellence Award (MBEA). (2013). Brochure, Ministry of Industry, Commerce \& Consumer Protection.

McDonald, I., Zairi, M., \& Idris, M. A. (2002). Sustaining and transferring excellence. Measuring Business Excellence, 6(2), 20-30.

Ministry of Industry, Commerce and Consumer Protection (MICCP). (2012). Mauritius Business Excellence Award 2011(MBEA), Minister's Speech Award Ceremony of 4th Edition, Friday 29 June 2012, Le Meridien Hotel, Mauritius.

Ministry of Industry, Science and Research (MOISCR). (2009). Minister' Speech on the On the Occasion of the Explanatory Workshop of the Mauritius Business Excellence Award 2009 on 6 May 2009 at Rajiv Gandhi Science Centre. Port Louis, Mauritius.

National Institute of Standards and Technology (NIST). (2006). Criteria for Performance Excellence 2006: Baldrige National Quality Program, US Department of Commerce, Gaithersburg, MD: National Institute of Standards and Technology.

National Institute of Standards and Technology (NIST). (2007). Criteria for Performance Excellence 2007: Baldrige National Quality Program, US Department of Commerce, Gaithersburg, MD: National Institute of Standards and Technology.

National Institute of Standards and Technology (NIST). (2008). Criteria for Performance Excellence 2008: Baldrige National Quality Program, US Department of Commerce, Gaithersburg, MD: National Institute of Standards and Technology

National Institute of Standards and Technology (NIST). (2009). Criteria for Performance Excellence 2009-2010: Baldrige National Quality Program, US Department of Commerce, Gaithersburg, MD: National Institute of Standards and Technology.

National Institute of Standards and Technology (NIST). (2011). Criteria for Performance Excellence 2011-2012: Baldrige National Quality Program, US Department of Commerce, Gaithersburg, MD: National Institute of Standards and Technology.

National Institute of Standards and Technology (NIST). (2013). Criteria for Performance Excellence 2013-2014: Baldrige National Quality Program, US Department of Commerce, Gaithersburg, MD: National Institute of Standards and Technology.

National Institute of Standards and Technology (NIST). (2015). Criteria for Performance Excellence 2015-2016: Baldrige National Quality Program, US Department of Commerce, Gaithersburg, MD: National Institute of Standards and Technology.

National Institute of Standards and Technology, (NIST). (2005). Criteria for Performance Excellence 2005: Baldrige National Quality Program, US Department of Commerce, Gaithersburg, MD: National Institute of Standards and Technology.

National Institute of Standards and Technology. (2009). Criteria for Performance Excellence 2009-2010: Baldrige National Quality Program, US Department of Commerce, Gaithersburg, MD.

Peters, T., \& Waterman, R. (1982). In Search of Excellence: Lessons from America's Best Run Companies, Harper and Row, New York, NY.

SAI Global. (2010). 2010 Australian Business Excellence Award. Retrieved from http://www.sai-global.com

Talwar B. (2011). Comparative study of framework, criteria and criterion weighting of excellence models. 
Measuring Business Excellence, 15(1), 49-65, Q Emerald Group Publishing Limited

Talwar, B. (2008). Evolution of 'Universal Business Excellence Model' incorporating Vedic philosophy. Indian Institute of Technology.

Talwar, B. (2010). Business excellence models and the path ahead. The TQM Journal, 23(1), 21-35.

\section{Copyrights}

Copyright for this article is retained by the author(s), with first publication rights granted to the journal.

This is an open-access article distributed under the terms and conditions of the Creative Commons Attribution license (http://creativecommons.org/licenses/by/4.0/). 